\title{
JANINA DZIK
}

\section{KILKA UWAG O TWÓRCZOŚCI MALARZA TRYNITARSKIEGO JOHANNA PRECHTLA ${ }^{1}$}

Fotografia ze zbioru Michała Greima w kolekcji Polskiej Akademii Umiejętności przedstawiająca ołtarz główny w kościele potrynitarskim w Kamieńcu Podolskim pozwala na ustalenie dotychczas nieznanego, zniszczonego dzieła malarza trynitarskiego Johanna Prechtla ${ }^{2}$. Jest to iluzjonistyczna kolumnowa struktura zawierająca figurę Chrystusa Miłosiernego (Jesús Nazareno Rescatado), otoczoną przedstawieniami imitującymi rzeźby w charakterze prefiguracji Chrystusa (Jana Chrzciciela z barankiem i Abrahama z Izaakiem oraz Hioba i Józefa z Egiptu - ?) (fot. 1). Unikatowe ujęcie wnętrza przed zmianą wielkiego ołtarza podczas gruntownego remontu kościoła w 1907 r. $^{3}$, jest jedynym znanym dziełem Prechtla w tym mieście, gdzie artysta, zdaniem Edwarda. Rastawieckiego, miał wykonać w 2. poł. XVIII w. dekoracje malarskie al fresco i obrazy dla katedry w Kamieńcu Podolskim oraz dekoracje we wspomnianym kościele Trynitarzy ${ }^{4}$. Miasto to po okresie okupacji tureckiej (1672-1699) przeżywało okres stabilizacji, a renowacji poddano zaniedbane dotychczas budowle sakralne, m.in. z inicjatywy Adama Krasińskiego, biskupa kamienieckiego w latach $1760-1795^{5}$. Niestety, obydwa dzieła Prechtla nie zachowały się.

1 Por. mój artykuł: Johann Prechtl (1737-1799), ein unbekannter Maler aus Wien, und seine Werke in den östlichen Gebieten des ehemaligen Königreichs Polen, zamieszczony w „Barockberichte” t. 63, 2015. Niniejsze opracowanie na bazie wyżej wymienionego stanowi próbę zapoznania się z twórczością artysty.

2 J. M. Dziewulska, Świat Podola i Besarabii w obiektywie Michała Greima. Dary fotografii dla Polskiej Akademii Umiejętności [w:] „Rocznik Biblioteki Naukowej PAU i PAN w Krakowie”, LVI 2011, s. 38.

3 A. Prusiewicz, Kamieniec Podolski, Szkic historyczny, Warszawa 1915, s. 75.

4 E. Rastawiecki, Stownik malarzy polskich, t. 3, Warszawa 1957, s. 373; A. Prusiewicz, op. cit., s. 35. Nawa główna i boczne malowane w 1850 r. Brak informacji o freskach Prechtla. Nie wspomina o nich również opracowanie Z. Bania, M. Wiraszka, Kamieniec Podolski. Miasto-legenda. Zarys dziejów urbanistyki i architektury od czasów najdawniejszych do współczesności, Warszawa 2001.

5 Z. Bania, M. Wiraszka, op. cit., s. 23-30. 
Odkrycie fotografii stanowi asumpt do rozważań nad trynitarskim artystą czynnym na Kresach Wschodnich. Jan Prechtl (Prächtl, Prestl), trynitarz, w zakonie Józef od św. Teresy (1737 Wiedeń-1799 Brahiłów) należy do znanych, lecz mało zbadanych malarzy XVIII w. Większość bowiem jego prac znajdujących się w klasztorach na terenie obecnej Ukrainy uległa zniszczeniu podczas konfliktów wojennych i w czasie komunistycznego reżimu. Podstawy artystycznego wykształcenia otrzymał on prawdopodobnie w Akademii Sztuk Pięknych w Wiedniu. W młodym wieku udał się z nieznanych przyczyn na Wołyń na ziemiach południowo-wschodnich dawnej Rzeczypospolitej, gdzie 6 marca 1758 r. w Beresteczku wstąpił do zakonu trynitarzy ${ }^{6}$.

Prechtl, malarz pochodzący z Austrii, jak pisał o nim Andrzej Ryszkiewicz w biogramie zawartym w Polskim słowniku biograficznym, tworzył przede wszystkim dla kościołów i klasztorów swego macierzystego zakonu. Był jedynym znanym malarzem trynitarskim 2. połowy XVIII w. na kresach południowo-wschodnich. Uważany za człowieka niezwykle pracowitego, pozostawił ogromny dorobek, zupełnie dotychczas niezbadany, a znajdujący się poza obecnymi granicami Polski ${ }^{7}$. Doskonale operował iluzją przestrzeni, świetnie wykreślał perspektywę, swobodnie komponował wielkie płaszczyzny. W malowidłach sklepiennych zbliżał się do lekkości rokokowej, w obrazach natomiast pozostawał tradycyjnym artystą barokowym o doskonale opanowanej technice. Cieszył się sławą i uznaniem, a polichromie jego podziwiał sam król Stanisław August Poniatowski, który zatrzymał się w Brahiłowie podczas podróży do Kaniowa ${ }^{8}$.

Najstarsze informacje o artyście przekazane zostały przez Innocentego Krzyszkowskiego przełożonego klasztoru trynitarskiego na Antokolu wileńskim w książeczce pod tytułem Nabożeństwo wiernych katolików dla użycia pobożnego w domu $i$ wościołach..., wydanej w Wilnie w 1834 r.; wiadomość ta powtórzona została w artykule Jerzego Hoppena, Malarz Jan Prechtl - brat Józef od św. Teresy (1938/ 1039) ${ }^{9}$. O zwiedzaniu klasztoru łuckiego i znajdujących się tam dziełach malarza trynitarskiego pisał Józef I. Kraszewski w wileńskim „Athenaeum” (1844) ${ }^{10}$. Informacje te stały się źródłem dla not biograficznych malarza w Słowniku malarzów polskich (1851) Edwarda Rastawieckiego i Biographisches Lexikon des Kaiserthums

${ }^{6}$ A. Ryszkiewicz, Jan Prechtl [w:] Polski Stownik Biograficzny, t. 28, 1984, s. 412-413.

7 Tamże.

8 Tamże.

9 I. Krzyszkowski, Nabożeństwo wiernych katolików..., „Dodatek Wileński” 1834 ; J. Hoppen, Malarz Jan Prechtl - brat Józef od św. Teresy, „Prace i Materiały Sprawozdawcze Sesji Historyków Sztuki Towarzystwa Przyjaciół Nauk w Wilnie”, t. 3, 1838/1839, s. 150-155. Informacje te powtórzone zostały przez E. H. Iwanowskiego, Kilka rysów i pamiątek, 1860, s. 181-182, oraz A. Rollego Zameczki polskie na kresach multańskich 1880, s. 211, 299. Uwagi na temat Szarawki i znajdującego się tam kościoła podominikańskiego z zachowanymi malowidłami znalazły się w nocie Antoniego J. Rollego zamieszczonej w czasopiśmie „Kraj” (1884 A. J. [Antoni J.], [List], „Kraj”, 1884, nr 25, s. 11. „Dziennik Warszawski”, 1854, s. 152 (J. Bartoszewicz); A. Wojniewicz, Euck na Wotyniu, Łuck 1922, s. 29.

10 J. I. Kraszewski, Wspomnienia XX. Trynitarzy, „Athenaeum”, t. 5, 1844, s. 35. 
Österreich Constantina von Wurzbach (1872) oraz Allgemeinen Künstler Lexikon Ulricha Thieme i Felixa Beckera (Zygmunt Batowski, 1933) ${ }^{11}$, jak również wspomnianego już Andrzeja Ryszkiewicza w Polskim Słowniku Biograficznym (1984) i Aleksandry Bernatowicz w Stowniku Artystów Polskich (2007) ${ }^{12}$. Piotr Bohdziewicz w swoich artykułach na temat kościoła i klasztoru Bernardynów w Dubnie przypisał znajdujące się tam iluzjonistyczne malowidła Prechtlowi $(1959,1973)^{13}$. Malarz zakonny jako mistrz malarstwa kwadraturowego w wersji pozzowskiej wzmiankowany został przez Magdalenę Witwińską, Andrzeja Stogę i Jerzego Kowalczyka ${ }^{14}$, który zamieścił w swym artykule fotografie malowideł $\mathrm{z}$ Brahiłowa ze zbiorów Instytutu Architektury i Urbanistyki w Kijowie oraz ze BNAN-K, zbiór Taranuszenki ${ }^{15}$. Zaś Agnieszkia Łaguna-Chevillotte, w artykule poświęconym freskom Józefa Piltza w dawnym kościele Trynitarzy w Krakowie, wskazała na nieznane dotychczas malowidło Prechtla w Brahiłowie ${ }^{16}$. O obrazie Prechtla z dawnego kościoła Trynitarzy na Antokolu w Wilnie (przechowywanym w Litewskim Muzeum Narodowym w Wilnie) znalazły się informacje w publikacjach litewskich, a wynikiem badań Andrzeja Witko była zmiana identyfikacji trynitarskiego świętego na tymże obrazie ${ }^{17}$.

Znacząca część dzieł Prechtla została zniszczona podczas działań wojennych oraz w czasie komunistycznego reżimu. Badania prowadzone w ostatnich latach nad sztuką kresów wschodnich dawnej Rzeczypospolitej umożliwiły także dokładniejsze poznanie dokumentacji fotograficznej, w tym nieznanych dzieł osiemnastowiecznego malarza. Jednakże żadne z malowideł monumentalnych Prechtla na Podolu i Wołyniu nie dotrwało do naszych czasów, co uniemożliwia ich precyzyjną

${ }^{11}$ E. Rastawiecki, op. cit., t. 3, Warszawa 1957, s. 372; C. Wurzbach, Joseph Prechtl [w:] Biographisches Lexikon des Kaiserthums Österreich, t. 23, Wien 1872, s. 234; Z. Batowski, Józef Prechtl [w:] U. Thieme, F. Becker, Allgemeines Künstler Lexikon, t. 27, Leipzig 1933, s. 367.

${ }^{12}$ A. Ryszkiewicz, op. cit., s. 412-413; A. Bernatowicz, Jan Prechtl, w: Stownik Artystów Polskich, t. 8, red. U. Makowska, K. Mikocka-Rachubowa, Warszawa 2007, s. 10-11.

${ }_{13}$ P. Bohdziewicz, Kościót i klasztor pobernardyński w Dubnie, „Biuletyn Historii Sztuki”, t. 21, 1959, s. 398-400; P. Bohdziewicz, Kościót i klasztor oo. Bernardynów w Dubnie, [w:] P. Bohdziewicz, Studia z dziejów sztuki polskiej w okresie baroku i rokoka, Lublin 1973, s. 137-142, $150-155$.

${ }^{14}$ A. Stoga, Quadratura w malarstwie polskim XVIII w. Malowidła na sklepieniach, „Biuletyn Historii Sztuki, t. 42, 1980, s. 369, 372; M. Witwińska, Topografia i kierunki malarstwa ściennego w Polsce około połowy XVIII wieku, Biuletyn Historii Sztuki, t. 43, 1981, s. 192, 200.

15 J. Kowalczyk, Późnobarokowe kościoły i klasztory diecezji kijowskiej i dekanatu bracławskiego, w: Sztuka kresów wschodnich, t. 3, Materiały sesji naukowej, Kraków, październik 1996, red. J. K. Ostrowski, Kraków 1998, s. 36, il. 44; J. Kowalczyk, Świątynie późnobarokowe na Kresach, Warszawa 2006, s. 143, 181, il. 289, 299.

${ }^{16}$ A. Laguna-Chevillotte, Freski Józefa Piltza w dawnym kościele oo. Trynitarzy w Krakowie, „Modus, Prace z historii sztuki”, t. 6, 2005, s. 19-48.

17 Lietuvos TSR Dailés Muziejus. Lietuvos dailè XVI-XIX a., Wilno 1969, s. 40, 42, 53; Lietuvos vievolyny dailè, Vilnius 1998; A. Witko, Sztuka w stużbie Zakonu Trójcy Świętej w siedemnastym i osiemnastym stuleciu, Warszawa 2002, s. 263, il. 187. 
analizę. Zachowana dokumentacja fotograficzna pozwala jednak na ustalenie części nieznanego dotąd oeuvre malarza i weryfikację dotychczasowych danych, celem stworzenia podstaw skromnego monograficznego opracowania.

Wśród znanych prac tego malarza najwcześniej wykonana została prawdopodobnie polichromia w prezbiterium kościoła Franciszkanów obserwantów (Bernardynów) w Dubnie. Powstała ona prawdopodobnie w związku z pracami remontowymi wnętrza kościoła po pożarze, który wybuchł 20 marca 1764 r., niszcząc dach świątyni wraz z całym wyposażeniem wnętrza ${ }^{18}$. Bohdziewicz przypisał malowidła Prechtlowi, uzasadniając swoje odkrycie podobieństwami formalnymi z polichromią na sklepieniu nawy głównej kościoła Trynitarzy w pobliskim Beresteczku ${ }^{19}$. Prechtl bowiem - jak twierdził - pracował nie tylko dla rodzimego zakonu, ale również dla różnych kościołów „na zamówienie”. Bohdziewicz podkreślał wybitne wartości iluzjonistycznej architektury, opisując stan malowideł w prezbiterium przed II wojną światową, kiedy kościół objęli ponownie bernardyni, rozpoczynając prace renowacyjne i konserwatorskie, mające na celu przywrócenie pierwotnego wyglądu budowli ${ }^{20}$. Dzięki dokumentacji fotograficznej Henryka Poddębskiego i Piotra Bohdziewicza przechowywanej w Instytucie Sztuki PAN w Warszawie oraz publikacjom Piotra Bohdziewicza i Andrzeja Stogi znanych jest kilka ujęć wnętrza kościoła w Dubnie ${ }^{21}$.

Na sklepieniu prezbiterium namalowane zostało Wniebowzięcie Matki Boskiej w kształcie wydłużonej panoramy ujętej ramą, z unoszącą się Marią na tle iluzjonistycznej architektury z piętrzącymi się schodami. Postać Assunty z rozłożonymi rękami, dynamicznie podąża ku niebiosom, z których wyłaniają się trzej aniołowie. Otoczona jest postaciami ewangelistów w lunetach. Malowidło to wykazywało podobieństwa z rozwiązaniami kwadraturowymi z motywem wznoszących się schodów, charakterystycznych dla twórczości morawskiego malarza Johanna Georga Etgensa (1693-1757). Ściany naw częściowo - jak pisał Bohdziewicz - a ściany i sklepienie prezbiterium całkowicie pokrywają malowidła, w nawach i na glifach okien prezbiterium znajduje się „płaska dekoracja w guście rokoka”, na ścianach bocznych prezbiterium ,sceny figuralne z życia św. Rodziny”22. Były to kolejno od lewej: Pokłon pasterzy, Ucieczka do Egiptu, św. Rodzina ze św. Janem oraz Pokłon Trzech Króli w dekoracyjnych iluzjonistycznych ramach ${ }^{23}$. Bohdziewicz podkreślał bogaty koloryt malowideł: tonacja strojów czerwone, niebieskie, szarobiałe, szaro-

${ }_{18}$ P. Bohdziewicz, Kościół i klasztor oo. Bernardynów w Dubnie, s. 139; A. Stoga, op. cit., s. 369,375 .

19 P. Bohdziewicz, Kościót i klasztor oo. Bernardynów w Dubnie, s. 150-154.

20 Tamże. Przed wybuchem II wojny światowej prace koordynowane były przez inż. Romualda Gürtlera.

${ }^{21}$ P. Bohdziewicz, Kościót i klasztor pobernardyński w Dubnie, Biuletyn Historii Sztuki, t. 21, 1959, s. 398-400; P. Bohdziewicz, Kościót i klasztor oo. Bernardynów w Dubnie, s. 150-155, il.11, 29, 29a, 30 .

${ }^{22}$ P. Bohdziewicz, Kościót i klasztor oo. Bernardynów w Dubnie, s. 152-153.

${ }^{23}$ Tamże, s. 152. 
fioletowe, różowy i brazowo-żółty, a architektury - fioletowo-różowo-szarej oraz niebieskawo-jasnozielonej i żółtej imitującej złoto.

Znana z dokumentacji dekoracja nie była prawdopodobnie autentycznym malowidłem Prechtla, gdyż po kasacie zakonu (1853) w okresie zaborów freski zostały zamalowane w latach 1855-1875 podczas przebudowy i przekształcenia kościoła na cerkiew prawosławną ${ }^{24}$. Godna uwagi jest informacja przekazana przez Bohdziewicza o wzmiance dotyczącej polichromii przed jej przemalowaniem w pracy Nikołaja I. Teodorowicza $(1890)^{25}$. Pisał on, że na sklepieniu ołtarza namalowany był klęczący bernardyn, otrzymujący zwój z napisem Indulgentiae plenariae z rąk Matki Boskiej, przedstawionej wśród obłoków i otoczonej aniołami, zaś „,w kątach czterej papieże w tiarach". Postać bernardyna, zapewne podczas przebudowy kościoła na sobór prawosławny w r. 1873, pokryto obłokami i na ich tle namalowano kilku cherubów, a napis na zwoju zastąpiono słowami: „Wielbi dusza moja Pana (Magnificat anima mea Dominum)" ${ }^{26}$. W kontekście opisu Teodorowicza, można założyć, że pierwotnie na sklepieniu prezbiterium znajdowała się scena z przedstawieniem obdarowania św. Franciszka odpustami przez Chrystusa i Marię, charakterystyczna dla ikonografii franciszkańskiej ${ }^{27}$.

Wydłużonemu prezbiterium kościoła nadany został ujednolicony charakter z wyeksponowaną centralną panoramą sklepienną, korespondujący z iluzjonistycznym, kolumnowym ołtarzem głównym, z przedstawieniem Niepokalanego Poczęcia NMP. Zarówno monumentalny wizerunek Immaculaty, jak i Trójca Święta w zwieńczeniu oświetlone były przez światło padające z góry z okna stanowiącego część iluzjonistycznej struktury ołtarzowej (fot. 2 ) $^{28}$.

Nieukończenie dekoracji kościoła, jak przypuszczać można, spowodowane zostało wyjazdem Prechtla do Krakowa. Prawdopodobnie celem wyjazdu było uzupełnienie dekoracji wykonanej przez morawskiego artystę Józefa Piltza w latach 1757-1758 po pożarze klasztoru w listopadzie $1765 \mathrm{r}^{29} \mathrm{~W}$ tym czasie powstało jedyne zachowane dzieło Prechtla, to jest polichromia w zakrystii kościoła Zakonu Trójcy Świętej w Krakowie, sygnowana, wykonana w 1765 r. Malowidło ukazuje adorację Oka Opatrzności, symbolicznego znaku Trójcy Świętej przez Jana z Mathy i Feliksa $\mathrm{z}$ Valois, przedstawionych w habitach zakonnych $\mathrm{w}$ dynamicznym upozowaniu (fot. 3$)^{30}$.

24 Tamże, s. 139.

25 N. I. Teodorowicz, Wolyń w opisanii gorodow, miescieczek i sioł. Istoriko-statisticzeskoje opisanie cerkwie i prichodow Wotynskoj Jeparchii, t. 2, 1890, s. 873-874.

26 Tamże.

27 J. Dzik, Euntes in mundum universum praedicate evangelium. Programy ideowe osiemnastowiecznych malowideł kościołów zakonnych na ziemiach południowo-wschodnich dawnej Rzeczypospolitej, Kraków 2014, s. 102-104.

28 P. Bohdziewicz, Kościół i klasztor oo. Bernardynów w Dubnie, s. 153.

29 Protoculum Conventus Casimiriensis Ordinis Discalceatorum SS. Trinitatis Redemptionis Captivorum A.D. 1692-1797, BJ rkp 5844, k. 24 v, 33v, 34, 35.

${ }^{30}$ Katalog Zabytków Sztuki w Polsce, t. 4. Miasto Kraków, cz. 5, Kazimierz i Stradom, Kościoły i klasztory, 2, red. I. Rejduch-Samkowa, J. Samek, Warszawa 1994, s. 73, il. 172 (sygnatura odczytana 
Malowidła dla kościoła Trynitarzy pw. Trójcy Swiętej w B ereste c zku, gdzie początkowo osiadł Prechtl, wykonane zostały przez niego w 2. połowie XVIII wieku ${ }^{31}$. Były to polichromie na ścianach i sklepieniu kościoła, szesnaście obrazów ołtarzowych oraz na zewnątrz malowidło historyczne przedstawiające bitwę pod Beresteczkiem $(1651)^{32}$. Zarówno Piotr Bohdziewicz ${ }^{33}$, jak i Jerzy Kowalczyk ${ }^{34}$ podkreślali wybitny poziom quadraturowych malowideł Prechtla, odwołujących się do wzorów teoretyka perspektywy Jana Jacoba Schüblera ${ }^{35}$. W iluzjonistycznej architekturze dominuje - jak podkreślano - motyw monumentalnej, kolumnowej aediculi, w którą wkomponowane zostały przedstawienia figuralne. W przestrzeni aedikuli widoczna jest unosząca się gołębica Ducha Świętego, a na schodach - oznaczeni płomieniami apostołowie w egzaltowanych pozach, wraz z Marią, usytuowaną pośrodku na wywyższeniu. U dołu, na otwartej księdze widoczny fragment z sekwencji na dzień Zesłania Ducha Świętego: Veni Sanctae Spiritus reple tuorum corda Fi(delium) et tui amoris in eis ignem ascende. Scena otoczona jest iluzjonistyczną dekoracją z personifikacjami cnót: po lewej Fortitudo z mieczem i hełmem oraz Innocentia z barankiem apokaliptycznym. A po prawej Prudentia ze zwierciadłem i wężem oraz postać z cyrklem Iustitia, w medalionach prawdopodobnie sceny typologiczne - zapewne przejście Izraelitów przez Morze Czerwone (fot. 4).

We wnętrzu trójnawowego kościoła Świętej Trójcy w Brahiłowie (Braiłowie) wznoszonego z funduszy Franciszka Salezego Potockiego, ukończonego w r. 1778, znajdowały się iluzjonistyczne malowidła Jana Prechtla, należące do najwspanialszych realizacji malarskich na kresach Rzeczypospolitej. Wykonał on wielki cykl polichromii pokrywających sklepienie świątyni łącznie z kaplicami w latach 1767-1778 ${ }^{36}$. W kościele - jak pisał Jan Marek Giżyński - nawa środkowa i dwie boczne były wszędzie al fresco malowane ${ }^{37}$. Polichromia w Brahiłowie, jak zauważył Jerzy Kowalczyk, podobnie jak wcześniej powstałe malowidła Prechtla w kościele Trynitarzy w Beresteczku, świadczyły o znajomości wzorów teoretyka perspektywy Jana Jacoba Schüblera ${ }^{38}$. Odkryte klisze N. Szomina (przed 1988, neg. Instytut Architektury i Urbanistyki w Kijowie - wnętrze prezbiterium; malowidła na sklepieniu nawy głównej z 3. ćw. XVIII, fot. z ok. 1930 r. BNAN-K zbiór Tara-

jako J. Brechtl); A. Witko, Sztuka w stużbie Zakonu Trójcy Świętej, s. 263, il. 187, oraz BJ, rkp 5357, t. X, k. $125 \mathrm{v}-126 \mathrm{v}$.

31 J. Hoppen, op. cit., s. 150-155; A. Ryszkiewicz, op. cit., s. 412-413; A. Bernatowicz, op. cit., s. 10-11.

${ }^{32}$ M. Orłowicz, Ilustrowany przewodnik po Wolyniu, Łuck 1929, s. 297; A. Bernatowicz, op. cit., s. 10-11.

${ }^{33}$ P. Bohdziewicz, Kościót i klasztor oo. Bernardynów w Dubnie, s. 154, il. 33.

34 J. Kowalczyk, Późnobarokowe kościoły, s. 36, il. 21, 43, 44.

35 J. Kowalczyk, Światynie późnobarokowe..., s. 181.

36 J. Kowalczyk, Późnobarokowe kościoły, s. 36.

37 J. M. Giżycki [Wołyniak], Wspomnienie o trynitarzach na Wolyniu, Podolu i Ukrainie, Kraków 1909, s. 62, 67-68.

38 J. Kowalczyk, Światynie późnobarokowe, s. 181, il. 279, 299. 
nuszenki) stanowią jedyną dokumentację wnętrza kościoła w Brahiłowie ${ }^{39}$. Na sklepieniu trójprzęsłowej nawy głównej ukazana została, podobnie jak w Beresteczku, scena Zesłania Ducha Świętego (fot. 5) ${ }^{40}$, natomiast na sklepieniu prezbiterium widoczna jest scena Pokłonu Pasterzy (fot. 6) w falistej ramie (z motywami tralkowatymi pośrodku każdego z boków, z wyraźnie zaakcentowanymi narożami z postaciami ewangelistów). Pośrodku widoczna Maria z Dzieciątkiem otoczona pasterzami na tle perspektywicznej architektury. Ze zdobionych malowidłami sklepień naw bocznych znane są tylko dwie sceny ujęte falistą ramą. Na podobieństwo quadri riportati ukazane zostało: Wykupienie niewolników z rąk pogańskich przez Jana z Mathy i Feliksa Valois (fot. 7) oraz scena uzdrowienia chorego przez nieznanego świętego (Kajetan z Thiene) (fot. 8).

W pierwszej ze scen na sklepieniu nawy bocznej Jan Prechtl, jak zauważyła to Agnieszka Łaguna-Chevillote rozpatrująca zagadnienie malowideł Józefa Piltza (1712-1796) w krakowskim kościele Trynitarzy (1757), odwołał się do znaczącego dla ikonografii trynitarskiej obrazu przedstawiającego priorytety misji patriarchów zakonnych. Obydwaj święci z zakonu trynitarzy w pierwszej ze scen ukazani zostali w habitach z narzuconymi kapturami. Św. Jan z Mathy kładzie pieniądze przed siedzącymi za stołem Turkami, by opłacić wolność widocznych poniżej chrześcijan.

Druga, nieznana dotychczas, scena ukazuje dynamicznie upozowaną postać duchownego w ciemnej sutannie dokonującego uzdrowienia chorego. Wskazuje on jedną ręką na chorego, drugą na znak Opatrzności pojawiający się w jasności u góry. Cechy te są charakterystyczne dla nie zbadanej w pełni ikonografii św. Kajetana z Thiene (1480-1547), założyciela teatynów, włoskiej posoborowej formacji klerykanckiej, ukazywanego często podczas opieki nad chorym (lub podczas uzdrowienia N. Caffarelli) ${ }^{41}$. Wiadomo, że św. Kajetan cieszył się kultem w zakonie trynitarzy. Nigdy nie ogłoszono go patronem Zakonu Trójcy Świętej, jednak należał on do popularnych świętych w ikonografii trynitarskiej ${ }^{42}$.

Jako niezwykła rzadkość zachował się nieznany dotychczas projekt Prechtla szkic wykonany kredką przedstawiający iluzjonistyczną kompozycję figuralną quasi panoramy przeznaczoną na sklepienie, ukazującą adorację Trójcy Świętej przez duchownego. Wykonany kredką szkic ukazuje iluzjonistyczną kompozycję figuralną, która na podobieństwo sceny teatralnej otoczona jest z czterech stron balkonami (fot. 9). W centrum widoczna jest wizja wstawiennictwa duchownego przed Trójcą Świętą w otoczeniu aniołów. Ubrany jest w sutannę, komżę i mozzettę - zwraca się do Marii, przyjmującej pisemne prośby. Są one dostarczane przez gestykulujące i modlące się postaci z tłumu stojącego na iluzjonistycznych balkonach. Wysoki poziom artystyczny szkicu przemawia za autorstwem Prechtla, a potwierdza to mo-

39 J. Kowalczyk, Późnobarokowe kościoły, il. 21, 44, s. 36, 22, 44; J. Kowalczyk, Światynie późnobarokowe, 2006, il. 279, 299.

40 J. Kowalczyk, Późnobarokowe kościoty, s. 68, il. 44, s. 57, il. 22, s. 66, il. 20.

${ }^{41}$ F. Tschochner, Kajetan (Gaetano) von Thiene [w:] Lexikon der christlichen Ikonographie, Bol. 7, Rom-Freiburg-Basel-Wien 1974, szp. 261-263.

${ }^{42}$ A. Witko, Sztuka w stużbie Zakonu, s. 383. 
tyw kompozycyjny sceny z iluzjonistycznymi balkonami, zbliżony do wspomnianej kompozycji Pokłon pasterzy nad prezbiterium kościoła w Brahiłowie. Była to prawdopodobnie własna koncepcja artysty interpretacji chwały Kajetana z Thiene, uznawanego za orędownika i cudotwórcę.

Prechtl dekorował również pałac hrabiego Franciszka Czackiego w Boreml (Boremel; rej. Równe), który podczas polsko-rosyjskiej wojny 1830-1831, w czasie powstania listopadowego, został zniszczony ${ }^{43}$.

Artyście zakonnemu przypisana została przez J. Kowalczyka polichromia w kościele w Iwankowie (rej. Andruszówka, Żytomierz), który był cały al fresco malowany łącznie z pięcioma iluzjonistycznymi ołtarzami. Na fotografii wykonanej przez O. Płamienicką, widoczne są fragmentarycznie malowidła kopuły przedstawiające Jezusa wypędzającego przekupniów ze świątyni ujęte w potężną kwadraturę ${ }^{44}$.

Kościół trynitarzy pw. św. Michała Archanioła i Nawrócenia św. Pawła w Łu cku wg rękopisu zatytułowanego „Opisanie kościoła i klasztoru łuckiego xx. Trynitarzów w guberni żytomierskiej w 1816 r.: ,,wewnątrz cały jest malowany w różnych kolorach i w różnych wyobrażeniach", które częściowo zniszczone zostały szczególnie w kaplicach podczas przemarszu wojsk napoleońskich w 1812 r. ${ }^{45}$ Stecki pisał, że ściany kościoła, jak i korytarze pokryte są od stropu do dołu freskami przedstawiającymi dzieje zakonu w Polsce i w obcych krajach „o szczęśliwej kompozycji, wyrazie i kolorycie" ${ }^{46}$. Prechtl namalował prawdopodobnie również niektóre obrazy, jak sądzić można ze wspomnianego dokumentu, które znajdowały się w dwukondygnacyjnych ołtarzach bocznych. Po kasacie zakonu w 1845 r. i rozebraniu kościóła w 1869 r. obrazy przedstawiające św. Recesa i św. Jan Nepomucena przeniesione zostały z kościoła trynitarzy do katedry łuckiej (d. kościoła jezuitów, po pożarze w 1781 przekształconego na katedrę i odbudowanego w stylu klasycystycznym) pw. Trójcy Świętej i św. Apostołów Piotra i Pawła i umieszczone w ołtarzach w transepcie ${ }^{47}$. Wizerunek Recesa (Recessa), patrona Łucka, ukazanego w zbroi w półpostaci w profilu, z towarzyszącym aniołem (fot. 10) znajdował się w lewym ramieniu transeptu poniżej obrazu Wniebowzięcia Matki Boskiej Tadeusza Kuntzego. Prechtl był prawdopodobnie również autorem wizerunku św. Jana Nepomucena umieszczonego w ołtarzu wraz z obrazem Michała Archanioła Kuntzego ${ }^{48}$.

43 C. Wurzbach, op. cit., s. 234.

44 J. Kowalczyk, Późnobarokowe kościoły, s. 36, il. 43; J. Kowalczyk, Światynie późnobarokowe, s. 181, il. 298.

${ }^{45}$ Materiały dotyczace kościołów i klasztorów na Litwie, Białorusi $i$ Ukrainie z XVII-XIX w., zebrane przez Jana Marka Giżyckiego, BJ rkp 6331, s. 93 nn.

46 T. J. Stecki, Łuck starożytny i dzisiejszy, Kraków 1876, s. 209

47 J. Hoppen, op. cit., s. 153. Zob. też: R. Mączyński, Nowożytne konfesje polskie. Artystyczne formy gloryfikacji grobów świętych..., Toruń 2003, s. 556-557.

48 A. Wojnicz, Łuck na Wolyniu, opis historyczno-fizjograficzny, Łuck 1922, s. 22; M. Orłowicz, op. cit., s. 114; Reprodukcje zawarte w: L. Popek, Świątynie Wolynia, t. 1, Lublin 1997, s. 143, il. 326, 327) zniszczone podczas pożaru świątyni. Ze zbiorów APŁ 668/58 i ze zb. Jakuba Radziewanowskiego, wł. Lutoslaw Stachowski. 
Kompozycja ukazuje praskiego kapłana w stroju liturgicznym, w całej postaci, $\mathrm{z}$ towarzyszącym aniołem.

Na krużgankach klasztornych wg „Opisania kościoła i klasztoru...” znajdowały się naprzeciw okien obrazy (w liczbie 30) w ramach, ukazujące sceny z życia patriarchów zakonnych Jana z Mathy i Feliksa Valois oraz innych świętych, a pomiędzy oknami różnego rodzaju landszafty i mapy geograficzne, częściowo zniszczone w 1812 r. ${ }^{49}$ Malowidłami ozdobiony był refektarz oraz biblioteka. Sala biblioteki posiadała „na sklepieniu... malowanie alegoryczne, wzięte z tekstu Pisma Św., wypisanego nad drzwiami" - wykonane ok. 1777. Malowidło przedstawiało personifikację Mądrości (Sapientia) na tle świątyni siedmiokolumnowej oraz personifikacje siedmiu cnót" ${ }^{50}$.

Nie znane są natomiast malowidła w kościele Dominikanów p.w. Zwiastowania NMP w Szaraw ce (d. pow. Płoskirów) na Podolu, gdzie darzony był kultem obraz Matki Boskiej Różańcowej. Po przekształceniu kościoła w 1. poł. XIX w. na cerkiew prawosławną, w 1832/1884 r. widoczne były jeszcze ślady malowideł ${ }^{51}$. Według Stownika geograficznego Królestwa Polskiego i Litwy (1890) w kościele pozostały ,ślady malowideł roboty znanego Prathla”, które wykonane zostać miały około r. 1773, podczas prac restauracyjnych kościoła, z funduszy Ignacego Dulskiego ${ }^{52}$.

$\mathrm{Z}$ malowideł ołtarzowych wykonanych przez trynitarskiego artystę zachował się obraz przeznaczony do kościoła św. Piotra i Pawła na Antokolu w Wilnie (przeniesiony do Dailes Muziejus, obecnie w Muzeum Sztuki Litewskiej w Wilnie) ${ }^{53}$. Obraz Jana Prechtla powstały po $1770 \mathrm{r}$. przedstawiający zakonnika w habicie trynitarzy (fot. 11), trzymającego oburącz mały krzyż, uchodził za wizerunek zakonnego mistyka Michała de Sanctis (Hoppen, Ryszkiewicz, Tarandaitè) ${ }^{54}$. Andrzej Witko wskazując na brak atrybutów właściwych ikonografii wspomnianego trynitarza, uważa obraz za wizerunek Jana Chrzciciela de la Conception, reformatora zakonu. Jest to realistyczny, zindywidualizowany portret mężczyzny w średnim wieku, ukazanego na wprost na ciemnym tle, o poważnej twarzy okolonej ciemnym zarostem i głębokim skupionym spojrzeniu. Malowidło zdaje się wykraczać poza ramy portretu, wprowadzając w obszar wizerunków kultowych. Nie zachowały się również obrazy dla ołtarza św. Jana Nepomucena w lewej nawie bocznej katedry kamienieckiej, oraz Trójcy Świętej w prawej nawie, podczas restauracji (przed r. 1860) przeniesiony do kościoła w Starej Uszycy, gdzie znajdował się w wielkim ołtarzu. W kaplicy

${ }^{49}$ T. J. Stecki, op. cit, s. 14-15; M. Orłowicz, op. cit., s. 114, 123.

${ }^{50}$ J. Hoppen, op. cit., s. 155.

${ }^{51}$ A. J. [Antoni J.], [List], „Kraj” nr 25, 1884, s. 11; A. Wojnicz, Euck na Wolyniu, Łuck 1922, s. $22,29$.

52 Stownik geograficzny Królestwa Polskiego i Litwy, t. 11, 1890, s. 792-794.

53 D. Tarandaitè, Painting and sculpture an integral part of cloister decor and religious practice [w:] Lietuvos vievolyny dailé, Vilnius 1998, s. 71-72, cyt. za: A. Witko, Sztuka w stużbie Zakonu, s. 339 f., il. XXII; tenże, Od El Greca do Prechtla. Z ikonografii św. Jana Chrzciciela de la Concepcion reformatora trynitarzy, Roczniki humanistyczne, 4, Historia sztuki, 50, 2002 (Suplement), s. 133.

${ }^{54}$ A. Witko, Sztuka w stużbie Zakonu, s. 335, 339-340, 342, il. XXII. 
Niepokalanego Poczęcia NMP, we wspomnianej katedrze, był obraz tegoż imienia malowany przez Prechtla, oddany w 1900 r. do kościoła w Płoskirowie (obecnie Chmielnicki) ${ }^{55}$.

W świetle zgromadzonych reprodukcji dzieł Prechtla, o nienajlepszej jakości podkreślić należy zróżnicowany charakter obiektów świadczących o wysokim poziomie umiejętności artysty. Są to zarówno realizacje iluzjonistycznych ołtarzy, polichromii sklepień oraz obrazy ołtarzowe i projekt dekoracji sklepienia, utrzymane w duchu osiągnieć malarstwa kwadraturowego Pozza. Są to w większości obiekty zniszczone; jedynie malowidło w zakrystii kościoła trynitarzy w Krakowie oraz obrazy przechowywane w Wilnie i Łucku świadczą o stylu zakonnego malarza. Dają one jednak możliwość oceny poziomu artystycznego dekoracji i środków wyrazu artysty swobodnie posługującego się panoramą i kwadraturą. Analiza zachowanego materiału pozwala na uwagi odnośnie genezy kompozycji. Są to malowidła o zróżnicowanej kompozycji i koncepcji. Zarówno efektowne kompozycje kwadraturowe wywodzące się z recepcji rycin Schüblera, jak i sceny z motywem rozbudowanych schodów, podobnie jak w przypadku Piltza oraz Wojciechowskiego i Kłosowskiego, wyrastają ze wspólnego motywu - fresków Etgensa w kościele św. Jana w Brnie ${ }^{56}$, które jak udowodniła A. Łaguna-Chevillotte wywodziły się z koncepcji malowidła Tiepola na sklepieniu S. Maria del Rosario w Wenecji ${ }^{57}$. W rozwiązaniach w nawach bocznych widoczne są również zasady quadri riportati. Nieco inna jest stylistyka panoramicznego układu centralnej sceny. Unikatowa pozostaje koncepcja projektu sklepienia dla nieznanego wnętrza architektonicznego. Artysta stosował bogaty zasób dekoracji - motywy iluzjonistycznego gzymsu z kroksztynami, strop kasetonowy, rokokowe kartusze, wazony z kwiatami. W kształtowaniu postaci wyróżnia się bryłowatość, zwartość budowie, plastyczne wyczucie kształtu, zindywidualizowane rysy twarzy.

Istotne są również inspiracje wzorami graficznymi dla partii figuralnych. Rycina wiedeńskiego sztycharza Franza Leopolda Schmittnera (1703-1761), przedstawiającą wykup niewolników, która stanowiła pierwowzór zarówno dla kompozycji krakowskiej Piltza, jak i brahiłowskiej Prechtla. Scenie wykupu jeńców chrześcijańskich z rąk muzułmanów przez św. Jana z Mathy towarzyszył św. Feliks Valois odbierający z rąk anioła biały sztandar z trynitarskim krzyżem. Rycina wykonana około r. 1745 - jak wskazał praski historyk sztuki Pavel Preiss - była reprodukcją obrazu przedstawiającego misję zakonu autorstwa Franza Karla Palki (1724-1767),

55 A. Prusiewicz, op. cit., s. 34, s. 42-43. Obraz w Starej Uszycy zastąpiony nowym obrazem Trójcy Świętej pędzla Kazimierza Mireckiego. Obraz NMP w Płoskirowie zastąpiony figurą Matki Boskiej z Lourdes ok. 1910 r.

56 Die Handzeichnungen des 18. Jahrhunderts. Katalog Germ. Nationalmuseum Nürnberg, M. Heffels (red.), Nürnberg 1969, S. 96, Abb. 120; M. Knedlik, Johann Georg Etgens, in: Saur, Allgemeines Künstler-Lexikon. Die bildenden Künstler aller Zeiten und Völker, t. 35, 2002, s. 257; J. Dzik, Idea gloryfikacji Marii w polichromii sklepienia kościoła bernardynów w Leżajsku, „Biuletyn Historii Sztuki”, t. 71, 2009, s. 311.

57 A. Łaguna-Chevillotte, op. cit., 2005, s. 19-48. 
ucznia Antonia Bibieny. Obraz przeznaczony był do ołtarza głównego kościoła trynitarzy w Bratysławie ${ }^{58}$. Prechtl, podobnie jak Piltz, wykorzystał tylko część dolną graficznej kompozycji, ukazującej wykup niewolników. Rycina była też prawdopodobnie wzorem dla obrazów w galerii klasztoru łuckiego opisywanego przez Kraszewskiego.

Przedstawienie Zesłania Ducha Świętego, jak udało się ustalić, stanowiło kompilację kilku rycin przedstawiających wnętrze wieczernika z Marią i apostołami w dniu Pięćdziesiątnicy. W charakterze wzoru dla sceny figuralnej w obramieniu kwadratury ze wzornika Schüblera posłużyła grafika antwerpskiego rytownika Cornelisa Corta (1533-1578), który wykonał ją w r. 1574 według wzoru Giorgio Vasariego (1511-1574) ${ }^{59}$. Prechtlowi znana była również grafika Petera Paula Rubensa rytowana przez Corneliusa Galle w r. 1614, zamieszczona w Missale Romanum, wydanym przez Plantinianę, kierowaną przez Balthazara Moretusa. Świadczy o tym flankująca kompozycję postać z uniesioną ręką i wyraźnie zaznaczone języki ognia ${ }^{60}$. Dla aranżacji sceny na sklepieniu kościoła i jej detali istotna była inspiracja grafiką przedstawiającą Zestanie Ducha Świętego z serii Annus dierum sanctorum (Pentecoste) z około r. 1750 autorstwa Josefa Sebastiana i Johanna Baptista Klauberów i Gottfrieda Bernharda Göza ${ }^{61}$. Natomiast dla sceny w prezbiterium prawdopodobnie inspiracją był Pokłon pasterzy Francesco Giovane (Juuants) według Carla Maratty ${ }^{62}$, zaś wizerunek św. Kajetana z Thiene nawiązywał do obrazu Sebastiano Rossi ${ }^{63}$.

Dysponując zachowanymi fragmentami dekoracji ważniejszych dzieł Prechtla postawic można pytanie o genezę jego twórczości - opartą o graficzne wzorce, a w przypadku ołtarza w kościele bernardynów w Dubnie, zainspirowanym prawdopodobnie rozwiązaniem w Kollegienkirche w Salzburgu.

Artykuł jest próbą stworzenia krótkiej monografii wybitnego osiemnastowiecznego artysty, któremu przyszło działać na peryferiach kultury zachodniej Europy. Niezbadana dotychczas twórczość Prechtla plasuje go obok wybitnych freskantów w duchu Pozza - mistrzów kwadratury tej epoki - przybyszów z Moraw - Fran-

${ }^{58}$ L. Schütz, Felix von Valois [w:] Lexikon der christlichen Ikonographie, t. 6, Freiburg i. Br. 1974, szp. 232-233; A. Petrova-Pleskotova, Maliarstvo 18. storocia na Slovensku, Bratislava 1983, il. XV; P. Preiss, Franz Karl Palko (1724-1767). Ölskizzen, Zeichnungen und Druckgraphik, t. 15, Schriften des Salzburger Barockmuseums, Salzburg 1989, s. 10, 28; też, František Karel Palko, Život a dilo maliře sklonku středoevropskégo baroka a jeho bratra Františka Antonina Palka, Praha 1999, s. 62-64, 281, il. 45-47; A. Witko, Sztuka w stużbie Zakonu, s. 106.

${ }^{59}$ The illustrated Bartsch, t. 52, s. 119, 120. Unter deinen Schutz, 2005, s. 521; M. Pielas, Graficzne pierwowzory przedstawień ,Zesłania Ducha Świętego” w polskiej sztuce nowożytnej - wybrane przyktady [w:] Inspiracje grafika europejska w sztuce polskiej. Czasy nowożytne, Warszawa 2010, s. 208-209, il. 220. The Illustrated Bartsch 47 (21) 1987, S. 57 ff.; The Illustrated Bartsch 52, 1989, S. $39 \mathrm{ff}$.

${ }^{60}$ M. Pielas, op. cit., s. 226.

${ }^{61}$ Ibidem, s. 224. Zbiory graficzne i kartograficzne BJ, nr 1511 I, Albumy.

${ }^{62}$ he Illustrated Bartsch 47 (21) 1987, s. 57-59. Typ sceny Cormelis Cort (1533-1578) wg Marco Pino da Siena wg Unter deinen Schutz, s. 491, The Illustrated Bartsch 52, 1989, s. $39 \mathrm{nn}$.

${ }^{63}$ The Illustrated Bartsch 47 (21) 1987, s. 57 ff.; The Illustrated Bartsch 52, 1989, s. 39 ff. 
ciszka Grzegorza Ecksteina (ok. 1689-1741), jego syna Sebastiana (2. i 3. tercja XVIII w.) oraz współpracownika Józefa Majera (Mayera) (1. połowa XVIII w.), działających na terenie ziem ruskich Rzeczypospolitej. Jako zakonni malarze freskanci czynni byli też na tych terenach jezuita Andrzej Ahorn (1703-1772), franciszkanin Adam Swach (1668-1747), wywodzący się z Moraw oraz pijar Łukasz (Karol) Hübel (1722-1793) ze Śląska. Umiejętności malarzy obcego pochodzenia, dysponujących doskonalszym warsztatem i nowymi wzorami przyczyniały się do podniesienia poziomu rodzimej twórczości. Działalność ich może posłużyć określeniu wpływów środowisk artystycznych Wiednia i Moraw na terenach Kresów Wschodnich. Był to region o specyficznej kulturze, wynikającej z jego dziejów i położenia geograficznego - stanowił bowiem wschodni kres łacińskiego Zachodu i zachodni bizantyjskiej cywilizacji Wschodu. Tereny te sąsiadujące z otomańską Portą i prawosławną Rosją postrzegane były jako antemurale Christianitatis, zapora broniąca kraju i całej Europy przed zagrożeniami tureckimi, moskiewskimi czy tatarskimi. Na obszarze tym ścierały się wpływy dwóch kultur: kształtującej się pod wpływem Kościoła Wschodniego oraz związanej z Kościołem Rzymskim. Na wielowyznaniowym i wielonarodowosciowym terenie istotną rolę $\mathrm{w}$ propagowaniu religii i kultury Zachodu pełniły zakony prowadzące działalność misyjną w duchu potrydenckiej reformy.

\section{JANINA DZIK}

A FEW REMARKS ON THE WORK OF A TRINITARIAN PAINTER, JOHANN PRECHTL (1737-1799)

\section{Summary}

The discovery of a photograph from Michał Greim's collection in the collection of the Polish Academy of Arts and Sciences presenting the main altar in the Post Trinitarian church in Kamieniec Podolski gave an impulse to initiate the research into a little known oeuvre of a Vienna born Trinitarian painter, Johann Prechtl (in the convent Joseph of St. Theresa; 1737-1799). Most of his works from the monasteries located on the territory of today Ukraine were destroyed during the wars or in the times of a communist regime.

Probably the earliest among those known works of the painter is the polychrome in the presbytery of the church of the Order of Friars Minor "Observants" (Bernardines) in Dubin, a small town located near Beresteczko. Prechtl did not finish the decoration of the church probably because he went to Cracow to complete the decoration made by a Moravian artist, Joseph Plitz, after the fire of the monastery. It is a polychrome in the vestry of the Church of the Order of the Holy Trinity in Cracow, created in 1765 and depicting the adoration of the Eye of Providence, a symbolic sign of the Holy Trinity, by John of Malta and Felix of Valois.

The paintings for the Trinitarian Church of the Holy Trinity in Beresteczko, where Prechtl settled down initially, were created in the second half of the $18^{\text {th }}$ century. These were the polychromes on the walls and the vault of the church (the scene of the Descent of the Holy Spirit upon the Apostles), 16 altar paintings and a historical painting outside presenting the Battle at Beresteczko.

The interior of the three - nave Church of the Holy Trinity in Brahiłów (Braiłów), financed by Franciszek Salezy Potocki and completed in 1778, included the illusionistic paintings by Johann Prechtl, 
which constitute one of the finest works of art in eastern parts of Poland. In the years 1776-1778 he created a large series of the polychromes covering the vault of the temple and its chapels (the well known scenes The Adoration of the Shepherds, The Descent of the Holy Spirit upon the Apostles, Ransoming of the Slaves from the Pagans by John of Malta and Felix of Valois, and The Healing of a Sick by Saint Cajetan). The polychrome in the church in Iwanków (Andruszówka region, Żytomierz) has also been attributed to the convent artist by J. Kowalczyk. The entire church was painted al fresco including five illusionistic altars. On the only surviving photograph one can see fragmentary paintings of the dome depicting Jesus cleansing the temple, which are enclosed in a quadrature. However, nothing is known about the murals in the Dominican Church of the Annunciation in Szarawka (Płoskirów county), Podolia, which was turned into an orthodox church in the first half of the $19^{\text {th }}$ century, and those in the Czacki family's palace in Boremel ( Równe region).

A unique photo of the interior of the Trinitarian church in Kamieniec Podolski as it was before the change of the big altar during a complete renovation of the church in 1907 shows the only work of Prechtl in this city that is known to us, although according to Edward Rastawiecki, in the second half of the $18^{\text {th }}$ century Prechtl supposedly created painting decorations al fresco and paintings for the Kamieniec Podolski Cathedral as well as the decorations in the Trinitarian church.

According to the archival documents, the Trinitarian Church of St Michael Archangel and the Conversion of St Paul in Łuck was "all painted inside in different colours and images", which were partially destroyed, especially in the chapels, during the march of Napoleon's army in 1812. In the view of the archives, we can suppose that there were Prechtl's paintings in the two-storey side altars. After the dissolution of the order in 1845 and the deconstruction of the church in 1869, the paintings depicting St Reces and St John Nepomucen were moved from the Trinitarian church to the Łuck Cathedral.

From the altar paintings created by the Trinitarian artist one painting survived. Meant for the Church of St Peter and Paul in Antokol, Vilnius (moved to Dailes Muziejus, now in the Museum of Lithuanian Art in Vilnius), it presented the image of a reformer of the Order of the Trinitarians, John Baptist de la Conception (after 1770).

The skills of foreign painters working in eastern Poland, including Prechtl, Francis Gregory Eckestein and his son from Moravia, Jospeh Mayer and Łukasz (Charles) Hübel from Silesia, who used better techniques and new models contributed to the improvement of the level of our Polish art. 
(C) Copyright by Polska Akademia Umiejętności \& Autorzy, Kraków 2015 